Keywords: SCIX, DWPF, glass, melt rate

Retention: Permanent

\title{
Impact of Small Column Ion Exchange Streams on DWPF Glass Formulation: Melt Rate Studies
}
K. M. Fox
D. H. Miller
D. C. Koopman

April 2011

Savannah River National Laboratory Savannah River Nuclear Solutions, LLC Aiken, SC 29808

Prepared for the U.S. Department of Energy under contract number DE-AC09-08SR22470.

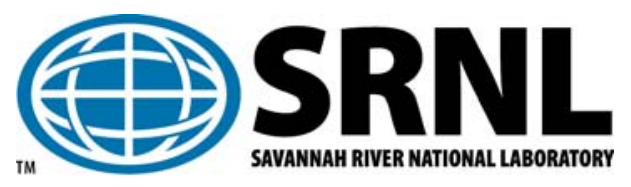


SRNL-STI-2011-00185

Revision 0

\section{DISCLAIMER}

This work was prepared under an agreement with and funded by the U.S. Government. Neither the U.S. Government or its employees, nor any of its contractors, subcontractors or their employees, makes any express or implied:

1. warranty or assumes any legal liability for the accuracy, completeness, or for the use or results of such use of any information, product, or process disclosed; or

2. representation that such use or results of such use would not infringe privately owned rights; or

3. endorsement or recommendation of any specifically identified commercial product, process, or service.

Any views and opinions of authors expressed in this work do not necessarily state or reflect those of the United States Government, or its contractors, or subcontractors.

\section{Printed in the United States of America \\ Prepared for \\ U.S. Department of Energy}




\section{REVIEWS AND APPROVALS}

AUTHORS:

K. M. Fox, Process Technology Programs

Date

D. H. Miller, Engineering Process Development

Date

D. C. Koopman, Process Technology Programs

Date

TECHNICAL REVIEW:

D. K. Peeler, Process Technology Programs

Date

APPROVAL:

C. C. Herman, Manager

Date

Process Technology Programs

F. M. Pennebaker, Manager

Date

SRNL SCIX Program

S.L. Marra, Manager

Date

Environmental \& Chemical Process Technology Research Programs

J. E. Occhipinti, Manager

Date

Waste Solidification Engineering

T. H. Huff, Manager

Date

SCIX Engineering 


\section{ACKNOWLEDGEMENTS}

The authors would like to thank Michael Stone, Jon Duvall, Pat Simmons, Whitney Riley, and David Best, for their assistance with the fabrication and characterization of the materials used in this study. 


\section{EXECUTIVE SUMMARY}

This study was undertaken to evaluate the potential impacts of the Small Column Ion Exchange (SCIX) streams - particularly the addition of Monosodium Titanate (MST) and Crystalline Silicotitanate (CST) - on the melt rate of simulated feed for the Defense Waste Processing Facility (DWPF). Additional MST was added to account for contributions from the Salt Waste Processing Facility (SWPF). The Savannah River National Laboratory (SRNL) Melt Rate Furnace (MRF) was used to evaluate four melter feed compositions: two with simulated SCIX and SWPF material and two without. The Slurry-fed Melt Rate Furnace (SMRF) was then used to compare two different feeds: one with and one without bounding concentrations of simulated SCIX and SWPF material. Analyses of the melter feed materials confirmed that they met their targeted compositions.

Four feeds were tested in triplicate in the MRF. The linear melt rates were determined by using $\mathrm{X}$-ray computed tomography to measure the height of the glass formed along the bottom of the beakers. The addition of the SCIX and SWPF material reduced the average measured melt rate by about $10 \%$ in MRF testing, although there was significant scatter in the data.

Two feeds were tested in the SMRF. It was noted that the ground CST alone (ground CST with liquid in a bucket) was extremely difficult to resuspend during preparation of the feed with material from SCIX and SWPF. This feed was also more difficult to pump than the material without MST and CST due to settling occurring in the melter feed line, although the yield stress of both feeds was high relative to the DWPF design basis. Steady state feeding conditions were maintained for about five hours for each feed. There was a reduction in the feed and pour rates of approximately 15\% when CST and MST were added to the feed, although there was significant scatter in the data. Analysis of samples collected from the SMRF pour stream showed that the composition of the glass changed as expected when MST and CST were added to the feed. These reductions in melt rate are consistent with previous studies that showed a negative impact of increased $\mathrm{TiO}_{2}$ concentrations on the rate of melting.

The impact of agitating the melt pool via bubbling was not studied as part of this work, but may be of interest for further testing. It is recommended that additional melt rate testing be performed should a potential reduction in melt rate of $10-15 \%$ be considered an issue of concern, or should the anticipated composition of the glass with the addition of material from salt waste processing be modified significantly from the current projections, either due to changes in sludge batch preparation or changes in the composition or volume of SCIX and SWPF material. 


\section{TABLE OF CONTENTS}

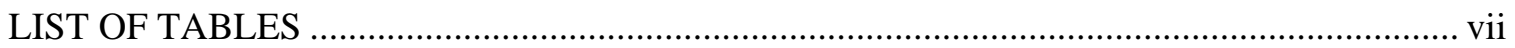

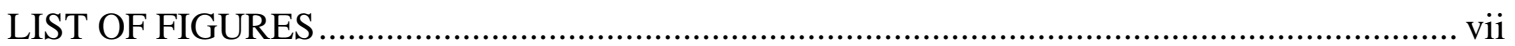

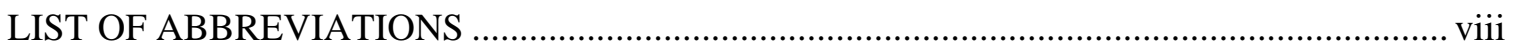

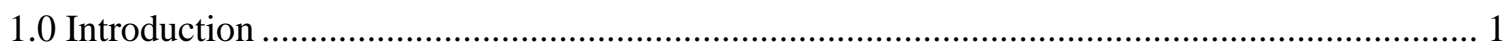

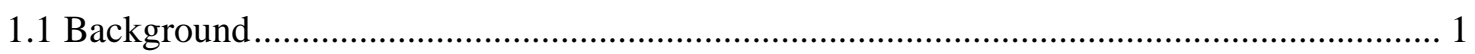

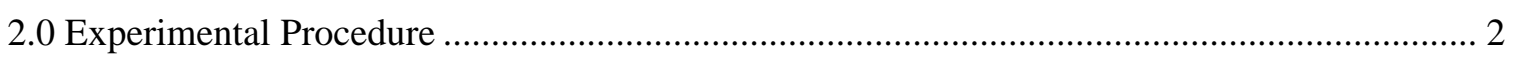

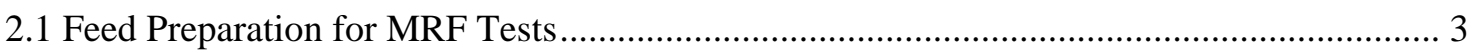

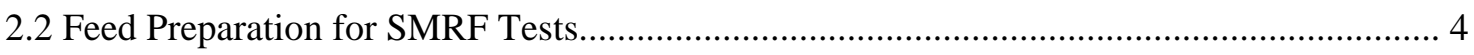

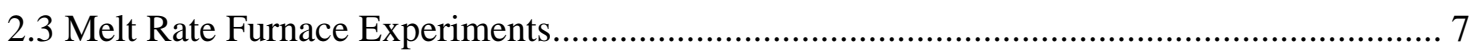

2.4 Slurry-fed Melt Rate Furnace Experiments .................................................................. 7

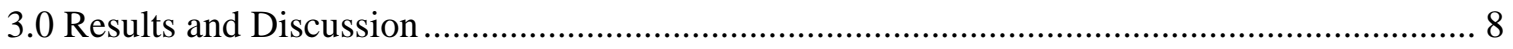

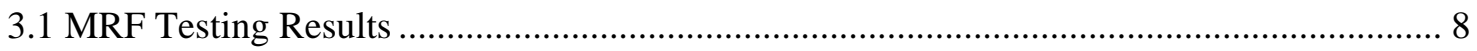

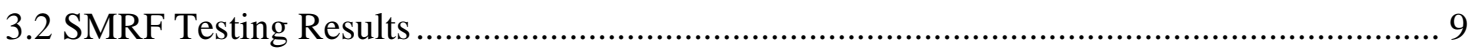

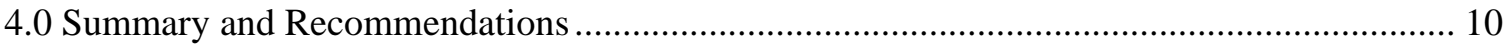

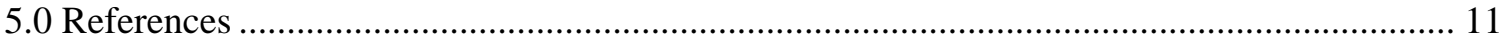




\section{LIST OF TABLES}

Table 1-1. Frit Compositions (wt \%) Used in Plodinec Study.................................................... 2

Table 1-2. Selected Properties of Glass Compositions from Plodinec Study................................. 2

Table 2-1. Measured Compositions (wt \%) of the SME Products Used for MRF Testing............ 4

Table 2-2. Measured Compositions (wt \%) of the SMRF Feed Materials after Calcining at

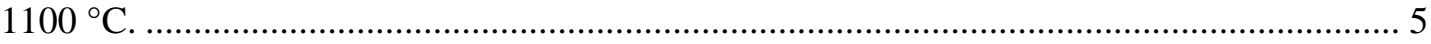

Table 2-3. Selected Properties of the SMRF Feeds................................................................... 6

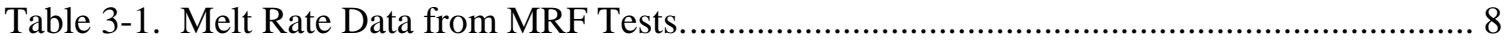

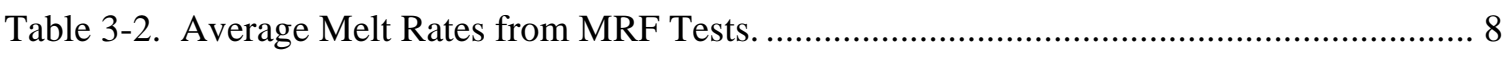

Table 3-3. Steady State Melt Rate Data from SMRF Tests......................................................... 9

Table 3-4. Measured Compositions (wt \%) of SMRF Pour Stream Samples. ............................... 10

\section{LIST OF FIGURES}

Figure 2-1. Flow curve comparison of the two melter feeds..................................................... 6 


\section{LIST OF ABBREVIATIONS}

$\begin{array}{ll}\text { CPC } & \text { Chemical Processing Cell } \\ \text { CST } & \text { Crystalline Silicotitanate } \\ \text { DWPF } & \text { Defense Waste Processing Facility } \\ \text { HLW } & \text { High Level Waste } \\ \text { MRF } & \text { Melt Rate Furnace } \\ \text { MST } & \text { Monosodium Titanate } \\ \text { REDOX } & \text { reduction / oxidation } \\ \text { RMF } & \text { Rotary Micro Filtration } \\ \text { SB6 } & \text { Sludge Batch 6 } \\ \text { SB6H } & \text { Harrell SB6 simulated SRAT material } \\ \text { SB10 } & \text { Sludge Batch 10 } \\ \text { SCIX } & \text { Small Column Ion Exchange } \\ \text { SME } & \text { Slurry Mix Evaporator } \\ \text { SMRF } & \text { Slurry-fed Melt Rate Furnace } \\ \text { SRAT } & \text { Sludge Receipt and Adjustment Tank } \\ \text { SRNL } & \text { Savannah River National Laboratory } \\ \text { SRS } & \text { Savannah River Site } \\ \text { SWPF } & \text { Salt Waste Processing Facility } \\ \text { VSL } & \text { Vitreous State Laboratory } \\ \text { WL } & \text { Waste Loading }\end{array}$




\subsection{Introduction}

\subsection{Background}

The Savannah River Site (SRS) Liquid Waste contractor will begin a process referred to as Small Column Ion Exchange (SCIX) to disposition salt solution in fiscal year 2014. In the first step of the process, salt solution retrieved from various waste tanks will be struck with Monosodium Titanate (MST) to remove key actinides and Sr. The salt solution will then be processed using Rotary Micro Filtration (RMF) to remove the MST and any insoluble solids. The MST and insoluble solids will accumulate on the bottom of Tank 41. The filtrate from RMF will be fed to ion exchange columns, also in Tank 41, to remove the ${ }^{137}$ Cs using Crystalline Silicotitanate (CST) resin. The decontaminated salt solution from SCIX will be sent to the Saltstone Facility for immobilization in grout. The ${ }^{137}$ Cs-laden CST resin will be sluiced and ground for particle size reduction, then sent to the Defense Waste Processing Facility (DWPF) for immobilization in glass. These processes mirror the current disposition paths for streams associated with the Salt Waste Processing Facility (SWPF), which is under construction and will run concurrently with SCIX.

The MST and insoluble solids from Tank 41 will periodically be transferred to a sludge batch preparation tank (e.g., Tank 42 or Tank 51) as part of the High Level Waste (HLW) sludge batch preparation process for DWPF. The ground, ${ }^{137}$ Cs-laden CST material (hereafter referred to simply as CST) from SCIX will be periodically transferred to Tank 40 prior to being processed at DWPF. Periodic additions of CST to Tank 40 would result in a changing composition of each sludge batch as it is processed since Tank 40 serves as the feed tank for the DWPF. Work is currently in progress to determine the feasibility of dropping the ground CST into Tank 41. If ground CST can be dropped into Tank 41 (depending on heat loading issues, among others), the CST would be sent to Tank 42 or Tank 51 using an existing transfer line. Therefore, the studies of SCIX impacts on DWPF glass formulation will encompass scenarios where the CST is sent to either Tank 40 or a sludge batch preparation tank. Additional MST will be included to account for contributions from the SWPF.

The MST and CST from the SCIX process will significantly increase the concentrations of $\mathrm{Nb}_{2} \mathrm{O}_{5}$, $\mathrm{TiO}_{2}$, and $\mathrm{ZrO}_{2}$ in the DWPF feed. Other constituents of MST and CST $-\mathrm{Na}_{2} \mathrm{O}$ and $\mathrm{SiO}_{2}-$ are already present in high concentrations in DWPF glass; thus their influences are well understood. The increased concentrations of $\mathrm{Nb}_{2} \mathrm{O}_{5}, \mathrm{TiO}_{2}$, and $\mathrm{ZrO}_{2}$ will likely have some impact on the properties and performance of the DWPF glass product. Properties such as the liquidus temperature, viscosity, and rate of melting of the glass may be impacted. The performance of the glass, particularly its chemical durability as it pertains to repository acceptance requirements, may also be impacted.

A series of recent reports on the potential impacts of SCIX on the properties and performance of DWPF glass have been issued. ${ }^{1-5}$ The objective of the study documented in this report is to evaluate the potential impacts of the SCIX streams on the melt rate of the DWPF glass product. Previous studies have reported marked reductions in melt rate when $\mathrm{TiO}_{2}$ concentrations in DWPF-type glasses were increased. ${ }^{6,7}$ A study by Plodinec evaluated the differences in melt rate for a DWPF-type glass when two different frit compositions were used: one containing $10 \mathrm{wt} \%$ $\mathrm{TiO}_{2}$ and one without $\mathrm{TiO}_{2}$ (Table 1-1). As shown in Table 1-2, the rate of melting was more than doubled when $\mathrm{TiO}_{2}$ was removed from the frit. 
Table 1-1. Frit Compositions (wt \%) Used in Plodinec Study. ${ }^{7}$

\begin{tabular}{||c|c|c||}
\hline Oxide & Frit 21 & Frit 211 \\
\hline $\mathrm{B}_{2} \mathrm{O}_{3}$ & 10.0 & 11.1 \\
\hline $\mathrm{CaO}$ & 5.0 & 5.6 \\
\hline $\mathrm{Li} 2 \mathrm{O}$ & 4.0 & 4.4 \\
\hline $\mathrm{Na}_{2} \mathrm{O}$ & 18.5 & 20.6 \\
\hline $\mathrm{SiO}_{2}$ & 52.5 & 58.3 \\
\hline $\mathrm{TiO}_{2}$ & 10.0 & 0 \\
\hline
\end{tabular}

Table 1-2. Selected Properties of Glass Compositions from Plodinec Study. ${ }^{7}$

\begin{tabular}{||c|c|c||}
\hline Frit Composition & Frit 21 & Frit 211 \\
\hline Viscosity (Poise) & 22 & 13 \\
\hline Maximum Waste Loading (wt \%) & 25 & 30 \\
\hline Melting Rate (g/min) & 4.1 & 9.8 \\
\hline
\end{tabular}

More recently, Lorier and Jantzen provided a technical basis for increasing the $\mathrm{TiO}_{2}$ concentration limit to $2.0 \mathrm{wt} \%$ in DWPF glass. As part of that study, they recommended that further melt rate studies be performed if $\mathrm{TiO}_{2}$ concentrations greater than 2 wt \% became necessary. ${ }^{8}$ The addition of streams from SCIX and SWPF will increase the concentration of $\mathrm{TiO}_{2}$ in the DWPF feed to well above $2 \mathrm{wt} \%$. The present study was undertaken to evaluate the potential impacts of the SCIX and SWPF streams - particularly the addition of MST and CST on the melt rate of simulated feed for the DWPF.

This work was initiated by a DWPF Technical Task Request ${ }^{9}$ and was performed following a Task Technical and Quality Assurance Plan. ${ }^{10}$

\subsection{Experimental Procedure}

Two of the furnaces available at the Savannah River National Laboratory (SRNL) for melt rate studies were utilized for this work. The Melt Rate Furnace (MRF) is a small scale melter used to evaluate the relative rate of melting of static, dry feeds. Dried feed material is heated inside a stainless steel beaker for a constant time period prior to removal. The furnace heating elements are configured such that the beaker is heated from the bottom only, to mimic the heating of a cold cap of feed material floating on a molten pool of glass. The MRF requires only small amounts of feed, and is therefore useful for rapid comparisons of multiple compositions. A detailed discussion of the MRF system and the technical basis for its operating conditions are available in a previous report. ${ }^{11}$

The Slurry-fed Melt Rate Furnace (SMRF) is a larger scale, liquid fed, continuous melter. The SMRF is used to evaluate melt rate on a larger scale with feeding conditions that are more similar to the full scale DWPF melter. Slurry feeding also allows for the evaluation of cold cap behavior. The MRF is typically used to screen compositions of interest prior to SMRF testing, since the SMRF requires a much larger amount of feed for each test. A detailed discussion of the SMRF system and the technical basis for its operating conditions are available in a previous report. ${ }^{11}$

For this study, the MRF was used to evaluate four feed compositions: two with simulated SCIX and SWPF material, and two without. The SMRF was then used to compare two different feeds: 
one with and one without simulated SCIX and SWPF material. The preparation of these feeds and the operation of the melters are described in the following sections.

\subsection{Feed Preparation for MRF Tests}

Material prepared at SRNL for other DWPF research and support activities was utilized for MRF testing. Four previously prepared Slurry Mix Evaporator (SME) products were used. The measured compositions of the SME products are given in Table 2-1. SME products SB10-7 and SB10-8 were prepared during tests at $100 \%$ and $150 \%$ acid stoichiometries, respectively, using a projected Sludge Batch 10 (SB10) composition feed simulant. They targeted a waste loading (WL) of 38\% with Frit 418. The preparation of these SME products is documented in a previous report. $^{12}$

SME products SCIX-1 and SCIX-2 were prepared during DWPF flowsheet simulations with a SB10 simulant trimmed to bounding levels with CST and MST from both SCIX and SWPF. The two DWPF simulations tested $100 \%$ and $150 \%$ acid stoichiometries, respectively, for a projected SB10 composition with added CST and MST. They targeted a WL of 39\% with Frit 418 . The preparation of these SME products is documented in a previous report. ${ }^{13}$ Simulated DWPF processing of CST and MST resulted in the leaching of most of the sodium from the CST and MST into the aqueous phase of the SME product along with the sorption of varying amounts of the potassium onto the CST (potassium is a fairly minor component of SB10 simulant). The sodium exchange is significant since the source of alkali (frit versus sludge) is known to have an impact on the SME product melt rate. ${ }^{14}$

A review of the data in Table 2-1 shows that the addition of $\mathrm{Nb}_{2} \mathrm{O}_{5}, \mathrm{TiO}_{2}$, and $\mathrm{ZrO}_{2}$ from $\mathrm{MST}$ and CST to the SCIX-1 and SCIX-2 products results in a reduction of the concentrations of the other oxides relative to those of the SB10-7 and SB10-8 products. Waste loadings calculated from knowledge of the starting sludge composition are approximately 39\%, as are the results for oxide material balance calculations performed on the DWPF flowsheet simulations. The measured WL values are similar for all of the SME products prepared for MRF testing. 
Table 2-1. Measured Compositions (wt \%) of the SME Products Used for MRF Testing.

\begin{tabular}{|c|c|c|c|c|}
\hline Oxide & SB10-7 & SB10-8 & SCIX-1 & SCIX-2 \\
\hline $\mathrm{Al}_{2} \mathrm{O}_{3}$ & 5.73 & 5.73 & 3.65 & 3.65 \\
\hline $\mathrm{B}_{2} \mathrm{O}_{3}$ & 4.26 & 4.25 & 4.54 & 4.59 \\
\hline $\mathrm{BaO}$ & 0.11 & 0.11 & 0.06 & 0.06 \\
\hline $\mathrm{CaO}$ & 1.50 & 1.52 & 0.78 & 0.78 \\
\hline $\mathrm{Ce}_{2} \mathrm{O}_{3}$ & - & - & 0.19 & 0.19 \\
\hline $\mathrm{Cr}_{2} \mathrm{O}_{3}$ & 0.11 & 0.11 & 0.05 & 0.05 \\
\hline $\mathrm{CuO}$ & - & - & 0.04 & 0.04 \\
\hline $\mathrm{Fe}_{2} \mathrm{O}_{3}$ & 17.66 & 17.26 & 9.06 & 8.94 \\
\hline $\mathrm{K}_{2} \mathrm{O}$ & 0.13 & 0.15 & 0.15 & 0.15 \\
\hline $\mathrm{La}_{2} \mathrm{O}_{3}$ & - & - & 0.06 & 0.06 \\
\hline $\mathrm{Li}_{2} \mathrm{O}$ & 4.47 & 4.54 & 4.37 & 4.42 \\
\hline $\mathrm{MgO}$ & 0.27 & 0.26 & 0.15 & 0.15 \\
\hline $\mathrm{MnO}$ & 2.54 & 2.42 & 1.52 & 1.51 \\
\hline $\mathrm{Na}_{2} \mathrm{O}$ & 12.43 & 12.00 & 13.18 & 13.24 \\
\hline $\mathrm{Nb}_{2} \mathrm{O}_{5}$ & - & - & 1.56 & 1.53 \\
\hline $\mathrm{NiO}$ & 0.45 & 0.46 & 0.21 & 0.22 \\
\hline $\mathrm{PbO}$ & 0.18 & 0.17 & 0.09 & 0.09 \\
\hline $\mathrm{SO}_{4}{ }^{2-}$ & 0.07 & 0.10 & $<0.10$ & $<0.10$ \\
\hline $\mathrm{SiO}_{2}$ & 50.22 & 50.53 & 48.88 & 49.63 \\
\hline $\mathrm{TiO}_{2}$ & 0.06 & 0.07 & 7.23 & 7.06 \\
\hline $\mathrm{ZnO}$ & 0.04 & 0.04 & 0.02 & 0.02 \\
\hline $\mathrm{ZrO}_{2}$ & 0.38 & 0.39 & 1.57 & 1.53 \\
\hline Sum & 100.6 & 100.1 & 97.4 & 97.9 \\
\hline
\end{tabular}

\subsection{Feed Preparation for SMRF Tests}

Two melter feeds were prepared to support the SMRF portion of the melt rate testing. The sludge waste component came from Sludge Batch 6 (SB6) Sludge Receipt and Adjustment Tank (SRAT) product simulant prepared at Harrell $(\mathrm{SB} 6 \mathrm{H})$. This slurry was used in preparing both melter feeds. The baseline melter feed included SB6H slurry mixed with Frit 418. The feed targeted a 40\% sludge loading on an oxide basis in glass. No SME cycle was performed. A total of 30 liters of baseline melter feed was prepared.

The second SMRF melter feed included SB6H slurry, frit, and resins from salt waste processing. Vitreous State Laboratory (VSL) performed grinding tests on the CST ion exchange resin as part of the grinder design work. A slurry of VSL ground CST was used in the preparation of the second melter feed. A slurry of MST qualified for the Actinide Removal Process was provided by Savannah River Remediation to prepare the second melter feed. The salt processing version of melter feed targeted $73 \%$ sludge oxides to $12 \%$ CST oxides to $15 \%$ MST oxides. These targets came from an earlier paper study. ${ }^{1}$ The sludge, CST, and MST constituted the waste oxides. Frit was added to the resulting blend targeting $60 \%$ frit oxides in glass (40\% sludge oxides, CST oxides, and MST oxides).

Simulant testing of the DWPF Chemical Processing Cell (CPC) with CST and MST indicated that significant leaching of sodium into the aqueous phase was occurring. ${ }^{13}$ An earlier DWPF melt rate study on the effect of the alkali source had indicated that alkali in the frit was not equivalent to alkali in the supernate. ${ }^{14}$ There was a potential for sodium in the CST and MST to not be leached in a blend of SB6H, CST, and MST that had never been heated to CPC processing 
temperatures. Therefore, it was decided to provide some processing time at boiling for the second melter feed slurry to allow the sodium in the MST and CST to migrate into the aqueous phase. CPC testing had indicated that about four hours at $93^{\circ} \mathrm{C}$ was more than sufficient to bring the sodium into the supernate phase. ${ }^{13}$ A 30 liter batch of melter feed slurry was prepared containing CST and MST. This slurry was divided in half. Both halves were refluxed in the SRNL 22-liter SRAT/SME rigs for four hours to allow insoluble sodium to stabilize in the preferred phase.

It was noted during the preparation of the SB6H-CST-MST blend that the VSL ground CST alone (ground CST with liquid in a bucket) was extremely difficult to resuspend. The ground solids had settled and formed a clay-like cake of material on the bottom of the container that had to be mechanically dislodged (direct contact of the mixing blades with the cake) before the CST could be slurried. This behavior could pose potential operational issues in full scale operations.

Samples of both melter feeds were obtained to verify that batching had been performed correctly. The compositional measurements are given in Table 2-2.

Table 2-2. Measured Compositions (wt \%) of the SMRF Feed Materials after Calcining at $1100{ }^{\circ} \mathrm{C}$.

\begin{tabular}{||c|c|c||}
\hline Oxide & SB6H-Frit 418 & SB6H-CST-MST-Frit 418 \\
\hline $\mathrm{Al}_{2} \mathrm{O}_{3}$ & 12.13 & 8.09 \\
\hline $\mathrm{B}_{2} \mathrm{O}_{3}$ & 6.44 & 4.99 \\
\hline $\mathrm{CaO}$ & 0.62 & 0.43 \\
\hline $\mathrm{Cr}_{2} \mathrm{O}_{3}$ & 0.04 & $<0.01$ \\
\hline $\mathrm{CuO}$ & 0.13 & 0.06 \\
\hline $\mathrm{Fe}_{2} \mathrm{O}_{3}$ & 10.98 & 7.45 \\
\hline $\mathrm{Li}_{2} \mathrm{O}$ & 4.67 & 4.97 \\
\hline $\mathrm{MgO}$ & 0.33 & 0.22 \\
\hline $\mathrm{MnO}$ & 3.18 & 2.12 \\
\hline $\mathrm{Na}_{2} \mathrm{O}$ & 13.99 & 16.31 \\
\hline $\mathrm{Nb}_{2} \mathrm{O}_{5}$ & $<0.14$ & 0.62 \\
\hline $\mathrm{NiO}_{\mathrm{SiO}}{ }^{2-}$ & 1.20 & 0.78 \\
\hline $\mathrm{SiO}_{2}$ & 0.45 & 0.30 \\
\hline $\mathrm{TiO}_{2}$ & 45.31 & 47.49 \\
\hline $\mathrm{ZnO}$ & 0.03 & 5.76 \\
\hline $\mathrm{ZrO}_{2}$ & 0.02 & $<0.01$ \\
\hline $\mathrm{Sum}^{2}$ & 0.11 & 0.59 \\
\hline \hline \multicolumn{2}{|c|}{} \\
\hline \multicolumn{2}{|c|}{} \\
\hline
\end{tabular}

The major sludge elements (Al, Fe, Mn, etc.) indicate that the melter feed with CST and MST had about $67 \%$ as much total sludge oxide content as the baseline melter feed slurry (versus the $73 \%$ targeted). The lithium indicates that the two waste loadings were very close to the target value. Several calculation approaches put the waste loading in the $38-42 \%$ range (versus the $40 \%$ targeted). ${ }^{\mathrm{a}}$ The predicted reduction / oxidation (REDOX) of the baseline feed was 0.234 $\mathrm{Fe}^{2+} / \Sigma \mathrm{Fe}$, while the predicted REDOX of the feed with CST and MST was 0.235.

\footnotetext{
${ }^{a}$ Using Fe to calculate waste loading yields 38.3\% WL for the SB6H-Frit 418 material and $38.7 \%$ WL for the SB6H-CST-MST-Frit 418 material.
} 
Selected additional properties of the two melter feeds are given in Table 2-3. The formate value for the SB6H-CST-MST-Frit 418 feed is higher than anticipated. The formate value was predicted to be closer to 55,000 $\mathrm{mg} / \mathrm{kg}$, and in addition, must be less than that of the SB6H-Frit 418 melter feed formate value based on the batching material balance (the formate fraction in the additions to SB6H was lower than the formate fraction in the SB6H slurry). Therefore, the projected formate value was used to make the REDOX prediction for the SB6H-CST-MST-Frit 418 melter feed.

Table 2-3. Selected Properties of the SMRF Feeds.

\begin{tabular}{||c|c|c||}
\hline Measurement & SB6H-Frit 418 & SB6H-CST-MST-Frit 418 \\
\hline Nitrate, $\mathrm{mg} / \mathrm{kg}$ & 24,580 & 24,850 \\
\hline Formate, $\mathrm{mg} / \mathrm{kg}$ & 58,150 & 64,900 \\
\hline Total solids, wt \% & 39.3 & 38.9 \\
\hline Insoluble solids, wt \% & 28.6 & 28.5 \\
\hline Soluble solids, wt \% & 10.7 & 10.4 \\
\hline Calcined solids, wt \% & 31.1 & 31.6 \\
\hline Slurry density, g/mL & 1.29 & 1.28 \\
\hline Yield Stress, Pa & 29 & 14 \\
\hline Consistency, cP & 30 & 23 \\
\hline \hline
\end{tabular}

Samples of the two melter feed slurries were run at $25^{\circ} \mathrm{C}$ on the Haake RS600 to obtain flow curve data. These data were fit to the Bingham plastic rheological equation to obtain yield stress and consistency (plastic viscosity). Four flow curves were obtained for each melter feed. Bingham plastic model fits given in Table 2-3 are averages of four values for the yield stress and consistency. The two most representative curves are shown graphically in Figure 2-1 to provide a visual comparison.

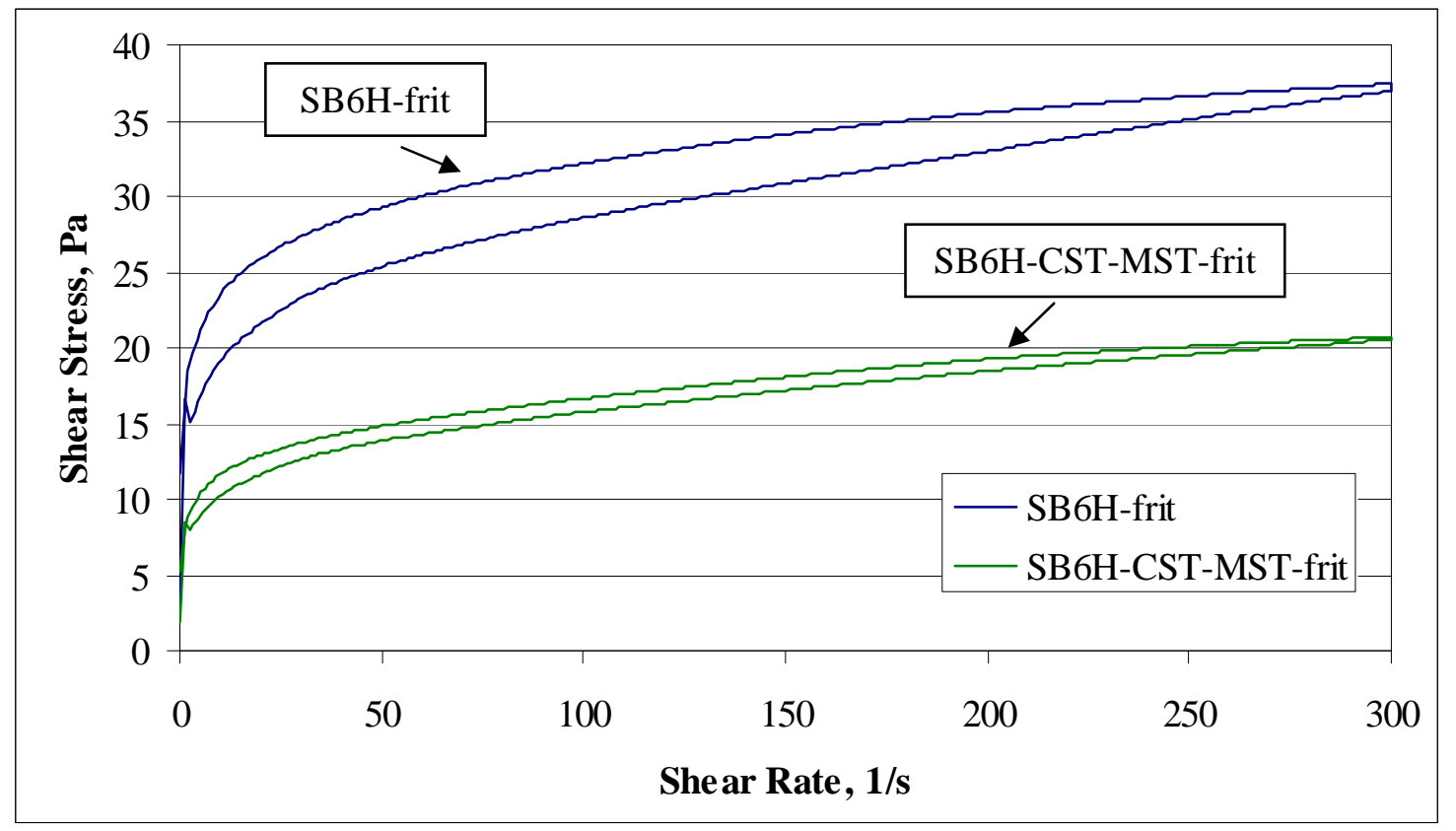

Figure 2-1. Flow curve comparison of the two melter feeds. 
The results were consistent with those in the report on SCIX impacts to the DWPF CPC. ${ }^{13}$ MST and ground CST combined with sludge tended to produce a less viscous melter feed slurry at a given insoluble solids loading.

\subsection{Melt Rate Furnace Experiments}

The SME products described in Section 2.1 were prepared for the MRF by drying at $90{ }^{\circ} \mathrm{C}$ and then screening through a 10 mesh $(1.7 \mathrm{~mm})$ sieve before being poured into a $125 \mathrm{ml}$ stainless steel beaker. Each SME product was tested in triplicate. The beaker was placed in an insulating sleeve and covered with a vented, insulating cover. The furnace was heated to $1150{ }^{\circ} \mathrm{C}$ with the top opening covered. Once the furnace reached the set point, the cover was removed and the beaker containing 65-74 g of SME product and frit was inserted. ${ }^{\text {a }}$ When inserted, the beaker bottom was approximately flush with the top of the uppermost chamber coil. The beaker was removed from the furnace after 20-25 minutes. ${ }^{\mathrm{b}}$ There was a 20 minute delay period between successive tests for the furnace to return to a stable temperature. After cooling, the linear melt rate was determined by using $\mathrm{X}$-ray computed tomography to measure the height of the glass formed along the bottom of the beaker.

\subsection{Slurry-fed Melt Rate Furnace Experiments}

The operational parameters for the SCIX tests in the SMRF were consistent with previous testing. More specifically, the melt pool and vapor space set points were $1125^{\circ} \mathrm{C}$ and $750{ }^{\circ} \mathrm{C}$, respectively. The time for each feed cycle after the vapor space had reached the feed initiation set point of $750{ }^{\circ} \mathrm{C}$ was 20 seconds. The measured current for the melt pool and vapor space heaters were both approximately $20 \mathrm{~A}$ for the two tests, indicating that the heating elements were operating as expected. Over the course of the two tests, a number of input and output parameters were monitored including feed rate and pour rate, cold cap behavior, and process temperatures (vapor space and melt pool).

Approximately $6 \mathrm{~kg}$ of glass made in 2010 from Frit 418 and Harrell SB6 simulated SRAT material (SB6H) was charged to the SMRF for startup. Heating of the melter began approximately 24 hours prior to the initiation of the first feed. Melter feed without the MST and CST additions was run on the first day of testing. Melter feed with the MST and CST additions was fed on the second day, and the melter was drained on the third day. The melter feed system was operated such that conditions as close to steady state as possible were maintained. Feed was added in $100 \mathrm{~g}$ increments over a period of 20 seconds each time the melter vapor space temperature returned to $750{ }^{\circ} \mathrm{C}$. The melter feed rate, pour rate, and temperature data were monitored and recorded using a computerized data acquisition system. These data were used to determine the steady state feed rate for each feed composition. Samples of the glass were collected from the pour stream at various times over the duration of the experiment. These samples were dissolved via sodium peroxide fusion and lithium metaborate fusion and analyzed via inductively coupled plasma - atomic emission spectroscopy to determine their chemical compositions.

\footnotetext{
${ }^{\mathrm{a}}$ The first two replicates used $65 \mathrm{~g}$ of material, and the third replicate used $74 \mathrm{~g}$ of material.

${ }^{\mathrm{b}}$ Melt times were increased over the course of testing to provide additional glass for measurement. The individual melt time for each beaker was recorded and used when calculating melt rates.
} 


\subsection{Results and Discussion}

\subsection{MRF Testing Results}

Three replicates were tested in the MRF for each of the four SME products. The measured melt rates for each test are listed in Table 3-1. As shown in Section 2.1, the measured compositions of the two feeds without the SCIX and SWPF material were nearly identical, as were the two feeds with the SCIX and SWPF material. The major difference among these feeds was acid stoichiometry. The data in Table 3-1 show that the melt rates measured for the SB10-7 feed (100\% acid stoichiometry) were consistently higher than those for the SB10-8 feed (150\% acid stoichiometry), despite targeting vary similar glass compositions. This is consistent with earlier melt rate studies completed with the SMRF, in that a higher acid stoichiometry reduced melt rate for the same glass composition. ${ }^{15}$ However, the data in Table 3-1 also show that the melt rates measured for the SCIX-1 feed (100\% acid stoichiometry) were consistently lower than those for the SCIX-2 feed (150\% acid stoichiometry), contradicting the earlier SMRF results. The earlier report also included data for MRF runs with feeds having varying acid stoichiometries. The report stated that the MRF results were inconclusive when acid stoichiometry was varied for the same feed composition. A recommendation was made that the MRF only be used to compare feeds resulting in a different glass composition, and that other differences in feed preparation be compared only with the SMRF. ${ }^{15}$ Therefore, the MRF results in this study were considered as groups on the basis of final glass composition in determining an average melt rate among the replicates for the compositions with and without the SCIX and SWPF material, as shown in Table 3-2.

Table 3-1. Melt Rate Data from MRF Tests.

\begin{tabular}{|c|c|c|}
\hline MRF Run Number & SME Material & Linear Melt Rate (in/hr) \\
\hline MRF 10-47 & SCIX-1 & 0.25 \\
\hline MRF 10-48 & SCIX-2 & 0.37 \\
\hline MRF 10-49 & SB10-7 & 0.42 \\
\hline MRF 10-50 & SB10-8 & 0.25 \\
\hline MRF 10-47a & SCIX-1 & 0.22 \\
\hline MRF 10-48a & SCIX-2 & 0.35 \\
\hline MRF 10-49a & SB10-7 & 0.42 \\
\hline MRF 10-50a & SB10-8 & 0.29 \\
\hline MRF 10-47b & SCIX-1 & 0.28 \\
\hline MRF 10-48b & SCIX-2 & 0.46 \\
\hline MRF 10-49b & SB10-7 & 0.54 \\
\hline MRF 10-50b & SB10-8 & 0.24 \\
\hline
\end{tabular}

Table 3-2. Average Melt Rates from MRF Tests.

\begin{tabular}{|c|c|c|}
\hline \hline SME Product ID & $\begin{array}{c}\text { Average Linear Melt rate (in/hr), } \\
\text { 6 replicates }\end{array}$ & $\begin{array}{c}\text { Standard Deviation } \\
\text { (in/hr) }\end{array}$ \\
\hline SB10 without SCIX and SWPF & 0.36 & 0.12 \\
\hline SB10 with SCIX and SWPF & 0.32 & 0.09 \\
\hline
\end{tabular}

The addition of the SCIX and SWPF material reduced the average measured melt rate by about $10 \%$ in MRF testing, although there was significant scatter in the data. Overall, the variation seen among the MRF measurements for each composition calls into question the true differences in melt rate among these feeds. The SMRF is expected to provide more definitive results. 


\subsection{SMRF Testing Results}

The first day of SMRF testing using the feed without CST and MST added went smoothly. There were no issues with pumping the feed to the melter. The feed formed an even cold cap on the surface of the melt pool, and no significant issues with foaming occurred. The pour rate matched the feed rate well based on the measured calcine factor of the feed. Steady state feeding conditions were reached after an initial startup period of approximately 2.5 hours, and were maintained for approximately 4.5 hours. Feed rate and pour rate data for the steady state period are shown in the left side of Table 3-3. Feeding was stopped after this period and the feed line was flushed with water. The melter was idled overnight.

The second day of SMRF testing using the feed with CST and MST added was more challenging. Frequent blockages of the feed line occurred during the startup period. The addition of CST and MST had the effect of thinning the feed (see Figure 2-1), which likely allowed solids to settle in the line between feeding cycles. Note however that this is likely a result of the relatively high yield stress of the SB6H material (Table 2-3), rather than being solely due to the addition of CST and MST. Efforts to minimize these blockages reduced their frequency during the steady state period of feeding, although they could not be eliminated. The startup period took approximately 5 hours due to the feed blockages. Steady state conditions were then maintained for approximately 5 hours. Feed rate and pour rate data for the steady state period are shown in the right side of Table 3-3. Note that while conditions were maintained as close to steady state as possible, there remained more variability in the feed and pour rates as compared to the data for the feed without CST and MST. Feeding was stopped after this period. The melter was idled overnight and drained on the following day.

Also included in Table 3-3 are the average feed and pour rates for the two feeds over the steady state periods. There was a reduction in the feed and pour rates of approximately $15 \%$ when CST and MST were added to the feed, although there was a significant amount of scatter among the data.

Table 3-3. Steady State Melt Rate Data from SMRF Tests.

\begin{tabular}{|c|c|c|c|c|c|}
\hline \multirow{2}{*}{$\begin{array}{c}\text { Time } \\
\text { (hours) }\end{array}$} & \multicolumn{2}{|c|}{$\begin{array}{c}\text { SB6H and Frit 418 without SCIX } \\
\text { and SWPF }\end{array}$} & \multicolumn{2}{|c|}{$\begin{array}{c}\text { SB6H and Frit 418 with SCIX } \\
\text { and SWPF }\end{array}$} \\
\cline { 2 - 6 } & $\begin{array}{c}\text { Feed Rate } \\
\text { (g/min) }\end{array}$ & $\begin{array}{c}\text { Pour Rate } \\
\text { (g/min) }\end{array}$ & $\begin{array}{c}\text { Feed Rate } \\
\text { (g/min) }\end{array}$ & $\begin{array}{c}\text { Pour Rate } \\
\text { (g/min) }\end{array}$ \\
\hline 0 & 33.1 & 11.2 & & 32.7 & 8.9 \\
\hline 0.5 & 45.6 & 11.7 & & 27.2 & 9.7 \\
\hline 1.0 & 32.9 & 11.4 & & 31.6 & 9.3 \\
\hline 1.5 & 39.2 & 11.7 & & 29.9 & 9.4 \\
\hline 2.0 & 32.6 & 12.8 & & 35.4 & 10.1 \\
\hline 2.5 & 36.1 & 13.7 & & 29.7 & 10.0 \\
\hline 3.0 & 35.6 & 11.1 & & 32.6 & 10.4 \\
\hline 3.5 & 37.6 & 10.8 & & 29.7 & 9.6 \\
\hline 4.0 & 33.1 & 11.2 & & 32.5 & 12.0 \\
\hline 4.5 & 42.3 & 12.4 & & 30.9 & 11.2 \\
\hline 5.0 & - & - & & 32.9 & 11.0 \\
\hline Average & $\mathbf{3 6 . 8}$ & $\mathbf{1 1 . 8}$ & & $\mathbf{3 1 . 4}$ & $\mathbf{1 0 . 1}$ \\
\hline
\end{tabular}

Five glass samples were collected from the SMRF pour stream during the testing. The measured compositions of these samples are given in Table 3-4. The results show that there was no 
contribution to the melt pool from MST or CST on Day 1, as expected. During Day 2, the higher $\mathrm{Nb}_{2} \mathrm{O}_{5}, \mathrm{TiO}_{2}$, and $\mathrm{ZrO}_{2}$ concentrations indicate that the MST and CST in the feed was increasing the concentration of these oxides in the melt pool, as expected. The results for the three samples taken during draining of the melter on Day3, when compared with the measured feed compositions in Table 2-2, show that a significant portion of the melt pool contained the elements from MST and CST after feeding of the SCIX and SWPF material on Day 2.

Table 3-4. Measured Compositions (wt \%) of SMRF Pour Stream Samples.

\begin{tabular}{|c|c|c|c|c|c|}
\hline "Sample ID & \multicolumn{5}{|c|}{ Description } \\
\hline SSG-01 & \multicolumn{5}{|c|}{ Pour stream sample from Day 1} \\
\hline SSG-02 & \multicolumn{5}{|c|}{ Pour stream sample from Day 2} \\
\hline SSG-03 & \multicolumn{5}{|c|}{ Pour stream sample from Day 3, after draining 2 kg } \\
\hline SSG-04 & \multicolumn{5}{|c|}{ Pour stream sample from Day 3, after draining $5 \mathrm{~kg}$} \\
\hline SSG-05 & \multicolumn{5}{|c|}{ Pour stream sample from Day 3, after draining $7.2 \mathrm{~kg}$} \\
\hline Oxide & SSG-01 & SSG-02 & SSG-03 & SSG-04 & SSG-05 \\
\hline $\mathrm{Al}_{2} \mathrm{O}_{3}$ & 11.42 & 11.21 & 9.73 & 9.80 & 9.46 \\
\hline $\mathrm{B}_{2} \mathrm{O}_{3}$ & 5.46 & 5.01 & 4.94 & 4.97 & 4.81 \\
\hline $\mathrm{CaO}$ & 0.58 & 0.58 & 0.50 & 0.51 & 0.47 \\
\hline $\mathrm{Cr}_{2} \mathrm{O}_{3}$ & 0.04 & 0.03 & 0.03 & 0.03 & 0.09 \\
\hline $\mathrm{CuO}$ & 0.09 & 0.09 & 0.08 & 0.09 & 0.09 \\
\hline $\mathrm{Fe}_{2} \mathrm{O}_{3}$ & 10.66 & 10.22 & 8.88 & 8.98 & 9.24 \\
\hline $\mathrm{Li}_{2} \mathrm{O}$ & 5.33 & 5.06 & 4.97 & 5.02 & 4.78 \\
\hline $\mathrm{MgO}$ & 0.33 & 0.32 & 0.28 & 0.28 & 0.27 \\
\hline $\mathrm{MnO}$ & 3.02 & 2.94 & 2.51 & 2.53 & 2.55 \\
\hline $\mathrm{Na}_{2} \mathrm{O}$ & 13.32 & 14.15 & 14.56 & 14.56 & 13.55 \\
\hline $\mathrm{Nb}_{2} \mathrm{O}_{5}$ & $<0.01$ & 0.15 & 0.50 & 0.49 & 0.45 \\
\hline $\mathrm{NiO}$ & 1.34 & 1.28 & 1.12 & 1.13 & 1.38 \\
\hline $\mathrm{SO}_{4}{ }^{2-}$ & 0.52 & 0.52 & 0.48 & 0.50 & 0.53 \\
\hline $\mathrm{SiO}_{2}$ & 47.07 & 45.78 & 45.78 & 47.07 & 46.42 \\
\hline $\mathrm{TiO}_{2}$ & 0.02 & 0.96 & 3.65 & 3.65 & 3.42 \\
\hline $\mathrm{ZnO}$ & $<0.01$ & $<0.01$ & $<0.01$ & $<0.01$ & $<0.01$ \\
\hline $\mathrm{ZrO}_{2}$ & 0.18 & 0.22 & 0.48 & 0.48 & 0.50 \\
\hline Sum & 99.37 & 98.51 & 98.42 & 100.02 & 97.94 \\
\hline
\end{tabular}

\subsection{Summary and Recommendations}

This study was undertaken to evaluate the potential impacts of the SCIX streams - particularly the addition of MST and CST - on the melt rate of simulated feed for the DWPF. Additional MST was included to account for contributions from the SWPF. The SRNL MRF was used to evaluate four feed compositions: two with simulated SCIX and SWPF material and two without. The SMRF was then used to compare two different feeds: one with and one without simulated SCIX and SWPF material. Analyses of the feed materials confirmed that they met their targeted compositions. Note that the CST and MST were added to the feeds at concentrations bounding the high end of the current projections; therefore, these concentrations may be greater than those encountered during typical operations.

Four feeds were tested in triplicate in the MRF. The linear melt rates were determined by using $\mathrm{X}$-ray computed tomography to measure the height of the glass formed along the bottom of the 
beakers. The addition of the SCIX and SWPF material reduced the average measured melt rate by about $10 \%$ in MRF testing, although there was significant scatter in the data.

Two feeds were tested in the SMRF. It was noted that the ground CST alone (ground CST with liquid in a bucket) was extremely difficult to resuspend during preparation of the feed with material from SCIX and SWPF. This feed was also more difficult to pump than the material without MST and CST due to settling occurring in the melter feed line, although the yield stress for both feeds was high relative to the DWPF design basis. Steady state feeding conditions were maintained for about five hours for each feed. There was a reduction in the feed and pour rates of approximately $15 \%$ when CST and MST were added to the feed, although there was significant scatter in the data. Analysis of samples collected from the SMRF pour stream showed that the composition of the glass changed as expected when MST and CST were added to the feed. These reductions in melt rate are consistent with previous studies that showed a negative impact of increased $\mathrm{TiO}_{2}$ concentrations on the rate of melting.

The impact of agitating the melt pool via bubbling was not studied as part of this work, but may be of interest for further testing. It is recommended that additional melt rate testing be performed should a potential reduction in melt rate of $10-15 \%$ be considered an issue of concern, or should the anticipated composition of the glass with the addition of material from salt waste processing be modified significantly from the current projections, either due to changes in sludge batch preparation or changes in the composition or volume of SCIX and SWPF material.

\subsection{References}

1. Fox, K. M., T. B. Edwards, M. E. Stone and D. C. Koopman, "Paper Study Evaluations of the Introduction of Small Column Ion Exchange (SCIX) Waste Streams to the Defense Waste Processing Facility,” U.S. Department of Energy Report SRNL-STI-2010-00297, Revision 0, Savannah River National Laboratory, Aiken, SC (2010).

2. Fox, K. M. and T. B. Edwards, "Impacts of Small Column Ion Exchange Streams on DWPF Glass Formulation: KT01, KT02, KT03, and KT04-Series Glass Compositions,” U.S. Department of Energy Report SRNL-STI-2010-00566, Revision 0, Savannah River National Laboratory, Aiken, SC (2010).

3. Fox, K. M. and T. B. Edwards, "Impacts of Small Column Ion Exchange Streams on DWPF Glass Formulation: KT05 and KT06-Series Glass Compositions,” U.S. Department of Energy Report SRNL-STI-2010-00687, Revision 0, Savannah River National Laboratory, Aiken, SC (2010).

4. Fox, K. M. and T. B. Edwards, "Impacts of Small Column Ion Exchange Streams on DWPF Glass Formulation: KT07-Series Glass Compositions," U.S. Department of Energy Report SRNLSTI-2010-00759, Revision 0, Savannah River National Laboratory, Aiken, SC (2010).

5. Fox, K. M. and T. B. Edwards, "Impacts of Small Column Ion Exchange Streams on DWPF Glass Formulation: KT08, KT09, and KT10-Series Glass Compositions,” U.S. Department of Energy Report SRNL-STI-2011-00178, Revision 0, Savannah River National Laboratory, Aiken, SC (2011).

6. Plodinec, M. J., "Development of Glass Compositions for Immobilization of SRP Waste,” U.S. Department of Energy Report DP-1517, Savannah River Laboratory, Aiken, SC (1979). 
7. Plodinec, M. J., "Improved Glass Compositions for Immobilization of SRP Waste”; pp. 223229 in Vol. 2, Proceedings of the International Symposium on the Scientific Basis for Nuclear Waste Management. Edited by C. J. M. Northrup, Jr. Plenum Press, New York, 1980.

8. Lorier, T. H. and C. M. Jantzen, "Evaluation of the $\mathrm{TiO}_{2}$ Limit for DWPF Glass," U.S. Department of Energy Report WSRC-TR-2003-00396, Revision 0, Westinghouse Savannah River Company, Aiken, SC (2003).

9. Fellinger, T. L., "Technical Task Request: DWPF Glass Evaluation for the Introduction of MSP Products into Future Sludge Batches," U.S. Department of Energy Report HLW-DWPFTTR-2010-0009, Revision A, Savannah River Remediation, Aiken, SC (2010).

10. Fox, K. M., “Task Technical and Quality Assurance Plan for Evaluation of the Introduction of Modular Salt Processing Products to Defense Waste Processing Facility Glass for Future Sludge Batches," U.S. Department of Energy Report SRNL-RP-2010-00560, Revision 0, Savannah River National Laboratory, Aiken, SC (2010).

11. Smith, M. E., T. H. Lorier and T. M. Jones, "SMRF and MRF DWPF Melt Rate Testing for SB2/SB3 (Case 6B-250 Canisters)," U.S. Department of Energy Report WSRC-TR-2003-00466, Westinghouse Savannah River Company, Aiken, SC (2003).

12. Lambert, D. P. and A. S. Choi, "DWPF Coal-Carbon Waste Acceptance Criteria Limit Evaluation Based on Experimental Work (Tank 48 Impact Study)," U.S. Department of Energy Report SRNL-STI-2010-00589, Revision 0, Savannah River National Laboratory, Aiken, SC (2010).

13. Koopman, D. C., "SCIX Impact on DWPF CPC," U.S. Department of Energy Report SRNLSTI-2011-00075, Revision 0, Savannah River National Laboratory, Aiken, SC (2011).

14. Lambert, D. P., D. H. Miller, D. K. Peeler, M. E. Smith and M. E. Stone, "Impact of Alkali Source on Vitrification of SRS High Level Waste," U.S. Department of Energy Report WSRCMS-2005-00319, Washington Savannah River Company, Aiken, SC (2005).

15. Smith, M. E., D. H. Miller and T. H. Lorier, "The Impact of Feed Preparation Acid Stoichiometry and Redox on Melt Rate for the SB3-Frit 418 Feed System,” U.S. Department of Energy Report WSRC-TR-2004-00350, Revision 0, Washington Savannah River Company, Aiken, SC (2004). 


\section{Distribution:}

J. W. Amoroso, 999-W

C. J. Bannochie, 773-42A

A. B. Barnes, 999-W

A. L. Billings, 999-W

J. M. Bricker, 704-27S

M. A. Broome, 704-29S

A. S. Choi, 773-42A

C. L. Crawford, 773-42A

D. A. Crowley, 773-43A

R. E. Edwards, 773-67A

T. B. Edwards, 999-W

T. L. Fellinger, 704-26S

S. D. Fink, 773-A

K. M. Fox, 999-W

B. J. Giddings, 786-5A

J. M. Gillam, 766-H

B. A. Hamm, 766-H

C. C. Herman, 999-W

D. T. Herman, 735-11A

R. N. Hinds, 704-S

E. W. Holtzscheiter, 704-15S

T. H. Huff, 773-66A
J. F. Iaukea, 704-30S

P. R. Jackson, 703-46A

C. M. Jantzen, 773-A

F. C. Johnson, 999-W

D. C. Koopman, 999-W

P. L. Lee, 703-41A

S. L. Marra, 773-A

D. W. Mcilmoyle, 766-H

D. H. Miller, 999-W

J. E. Occhipinti, 704-S

D. K. Peeler, 999-W

F. M. Pennebaker, 773-42A

J. W. Ray, 704-S

M. A. Rios-Armstrong, 773-66A

H. B. Shah, 766-H

D. C. Sherburne, 704-S

M. E. Smith, 704-30S

A. V. Staub, 704-27S

K. H. Subramanian, 766-H

M. E. Stone, 999-W

J. P. Vaughan, 773-41A 